\title{
Valuation of angiogenesis in bovine xenografts implanted in intracorporal sites of rabbits as models of in-vivo bioreactors
}

\author{
[Avaliação da angiogênese em xenoenxertos bovinos implantados em sítios intracorpóreos de \\ coelhos como modelos de biorreatores in vivo]

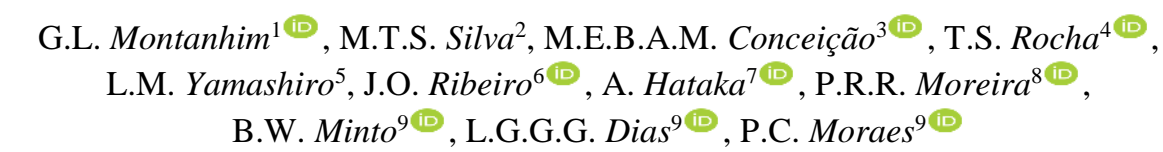 \\ ${ }^{1}$ Graduate, Faculdade de Ciências Agrárias e Veterinárias, FCAV/Unesp, Jaboticabal, SP, Brasil \\ ${ }^{2}$ Practitioner, Doha, Qatar \\ ${ }^{3}$ Practitioner, Belém, PA, Brasil \\ ${ }^{4}$ Universidade Brasil, Descalvado, SP, Brasil \\ ${ }^{5}$ Practitioner, Uberaba, MG, Brasil \\ ${ }^{6}$ Practitioner, Sorocaba, SP, Brasil \\ ${ }^{7}$ Faculdade de Medicina Veterinária e Zootecnia, FMVZ/Unesp, Botucatu, SP, Brasil \\ ${ }^{8}$ Centro Universitário de Rio Preto/Unirp, São José do Rio Preto, SP, Brasil \\ ${ }^{9}$ Faculdade de Ciências Agrárias e Veterinárias, FCAV/Unesp, Jaboticabal, SP, Brasil
}

\begin{abstract}
The aim of this study was to evaluate neovascularization of bovine xenografts implanted in intracorporeal sites of rabbits (bioreactors). 30 rabbits were used, divided into 6 groups, according to the evaluation time (7, 15, 30, 45, and 60 days); each animal received xenogenic implants in 3 different intracorporeal sites (A1 - omentum bag; A2 - intermuscular space of quadriceps femoris; A3 - subperiosteal of ilium bone). Histological assessments graded the presence of angiogenesis, the number of inflammatory cells, newly formed bone tissue, and the presence of giant cells. Histological analyses showed intense angiogenesis in all implanted xenografts. Presence of inflammatory infiltrate and giant cells at the A1 implant site and presence of bone neoformation at the A3 implant site were noted. Degeneration of implants and formation of a fibrous capsule were noted. When comparing the interaction of the site with the days of evaluation, statistical analysis showed a significant difference $(\mathrm{p} \leq 0.05)$ in any time of neovascularization analysis. The vascular endothelial growth factor (VEGF) and inflammatory cells of the omentum in its structure, may have contributed to the greater presence of neovessels and inflammatory cells, a fact that may indicate functionality as a possible bone substitute.
\end{abstract}

Keywords: bone substitute, neovascularization, osteoinduction, xenogeneic graft

\section{RESUMO}

O objetivo deste estudo foi avaliar a neovascularização de xenoenxertos bovinos implantados em sítios intracorpóreos de coelhos (biorreatores). Foram utilizados 30 coelhos, os quais foram divididos em seis grupos, de acordo com o tempo de avaliação (sete, 15, 30, 45 e 60 dias); cada animal recebeu implantes xenogênicos em três diferentes sítios intracorpóreos (A1 - bolsa de omento; $A 2$ - espaço intermuscular do quadríceps femoral; A3 - subperiosteal do osso ílio). Avaliações histológicas classificaram a presença de angiogênese, o número de células inflamatórias, de tecido ósseo neoformado e a presença de células gigantes. As análises histológicas mostraram intensa angiogênese em todos os xenoenxertos implantados. Observou-se presença de infiltrado inflamatório e células gigantes no local do implante Al e presença de neoformação óssea no local do implante A3. Ao mesmo tempo, a degeneração dos implantes e a formação de uma cápsula fibrosa foram observadas. Ao comparar a interação do local com os dias de avaliação, a análise estatística mostrou diferença significativa $(P \leq 0,05)$ em qualquer momento da análise de neovascularização. O fator de crescimento endotelial vascular (VEGF) e as células inflamatórias do omento em sua estrutura podem ter contribuído para a maior presença de neovasos e células inflamatórias, fato que pode indicar funcionalidade como possível substituto ósseo.

Palavras-chave: enxerto xenógeno, neovascularização, osteoindução e substituto ósseo 


\section{INTRODUCTION}

Bone healing studies are increasingly emphasized in orthopedics, especially regarding the reduction in healing time, which is still a challenge (Croci et al., 2003). In Veterinary Orthopedics, this challenge is greater since cases of bone consolidation failures are common for various reasons inherent to the patient or technical failure.

Thus, it is necessary to use alternatives that minimize such problems, and the use of biomaterials or the implementation of therapeutic methods and techniques that help increase and accelerate bone repair are fundamental, as well as total restoration of motor function. Biomaterial consists of material responsible for connecting biological systems, its function is to evaluate, treat, augment, or replace any tissue, organ or function that has been lost in an organism (Guiterres et al., 2005). The in vivo bioreactor system has been extensively studied in materials engineering, with satisfactory results, as it increases cell adhesion and stimulates formation of tissue around the implant, producing better quality material than in vitro bioreactors (Stevens et al., 2005; Uriel et al., 2008; Huang et al., 2013).

Bone grafts are considered ideal biomaterials as indicated in cases of osteomyelitis and non-union of fractures, because they stimulate consolidation, preservation of limbs, and complement corrective osteotomies (Keating and McQueen, 2001).

The use of xenogenic bone is reported in the literature (Oliveira et al., 2004; Lima Taga et al., 2008, Castro-Silva et al., 2009) the potential and ease of obtaining and the stock, makes it a promising material for filling bone defects (Johnson, 2014). Additionally, the process is accelerated by its association with autogenous factors in the omentum. Thus, future applications can be created using systems with in vivo bioreactors, mainly in the reconstruction of large bone defects.

Given the numerous challenges to perform complicated bone repairs, either due to the choice of technique or the financial cost associated with them, the main objective of the present study was to evaluate the neovascularization capacity of bovine xenografts implanted in rabbit intracorporeal sites (in vivo bioreactors). In addition to the ease of obtaining and preparing bovine xenografts, it has a low implantation cost. When placed in the bioreactor - which can be the animal's own body - before being properly implanted in the bone gap, physiologically, it is assumed that from the moment they are revascularized, they will have osteoinductive and osteoconductive capacities.

\section{MATERIALS AND METHODS}

The experimental procedures were conducted according to ethical principles, approved by the Ethics Committee on the Use of Animals (CEUA) of FCAV / UNESP, Campus of Jaboticabal, Brazil, protocol number 7903/16.

Thirty young, New Zealand White, adult rabbits (Oryctolagus cuniculus) were used, 15 females and 15 males, each with an approximate body weight of $3 \mathrm{~kg}$; and distributed into 5 groups containing 6 rabbits (3 males and 3 females), according to the postoperative evaluation times (7, 15, 30, 45 and 60 days) of the xenograft implant site.

Implants were obtained from bovine scapula of animals slaughtered in a slaughterhouse. All soft tissues attached to the periosteum were removed and the bones were frozen for subsequent removal of the fatty portion of the bone marrow. The implants were made from the spongiest portion of the bones, in the form of $0.125 \mathrm{~cm}^{3}$ cubes and autoclaved in a low cycle $\left(121^{\circ} \mathrm{C}\right.$ for $15 \mathrm{~min}$ sterilization and 15 min drying) (Figure 1).

Each animal received two implants in three locations, called a subgroup, as shown in Figure 1:

A1: intra-abdominal omentum bag. After exploratory celiotomy, an omentum bag was made, and the implants were housed inside. The omentum bag was sutured with 4-0 nylon thread. A2: intermuscular area of the thigh. Location between quadriceps muscles, below fascia lata and accessed by procedure described in literature (Johnson, 2014).

A3: subperiosteal region of the right ilium bone. After accessing the iliac crest (Johnson, 2014), the periosteum of the lateral face was raised, but remained attached to the adjacent musculature and to the ventrolateral iliac bone. Implants were placed between the iliac bone and the periosteum. 


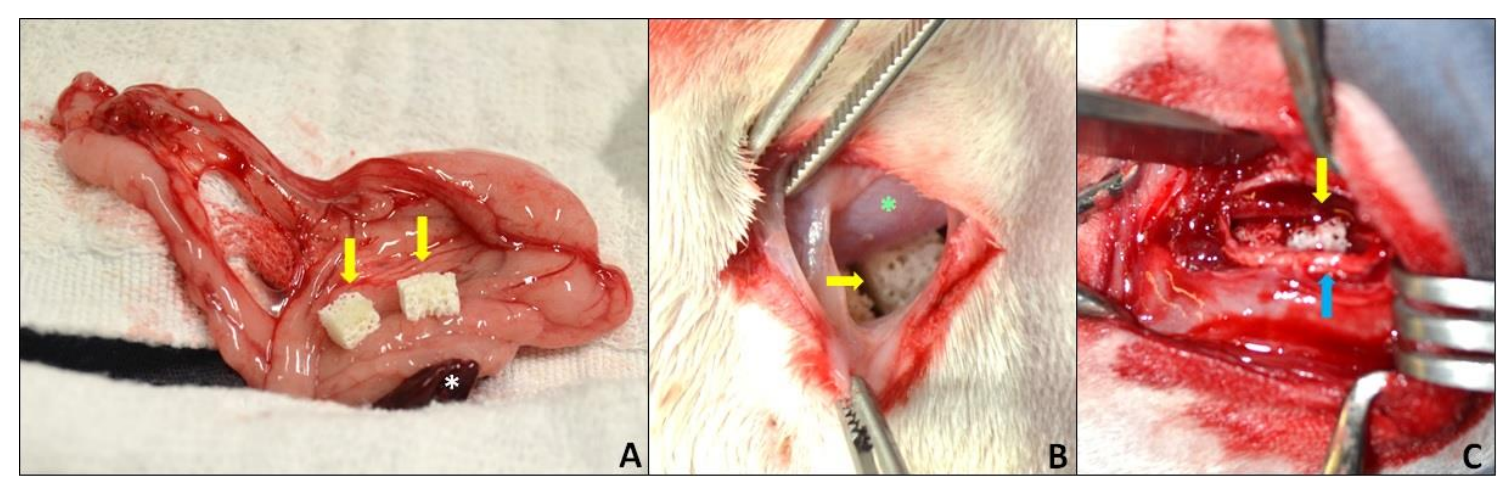

Figure 1. Bovine xenograft implantation sites (yellow arrow) in the bioreactor (rabbit Oryctolagus cuniculus). A: Implantation site A1 intra-abdominal omentum bag; after locating the omentum, which in the rabbit is intricately connected to the spleen (white asterisk), the implants were placed and a bag was made covering the implants with the omentum, taking care that the sutures did not strangle any large-caliber vessel in the organ. A2: Intermuscular implantation site, in which, after the dissected fascia and the quadriceps muscles spread apart (blue asterisk), the implants were housed within this space. A3: Subperiosteal implantation site, after surgical access to the ilium wing, the periosteum (blue arrow) separated from the bone and the implants were accommodated in this space; an approximation suture was made between the periosteum and the muscular fascia, to avoid the migration of the xenografts. Jaboticabal - SP, Brazil, 2021.

Animals were submitted to general dissociative anesthesia, acepromazine $0.2 \%(0.05 \mathrm{mg} / \mathrm{kg} \mathrm{IM})$ as pre-anesthetic medication, ketamine $(70 \mathrm{mg} / \mathrm{kg}$ $\mathrm{IM})$, and xylazine $(9 \mathrm{mg} / \mathrm{kg} \mathrm{IM})$ as anesthesia and trans-operative analgesic control.

In the immediate postoperative period, antimicrobial therapy was performed with enrofloxacin $2.5 \%$ dose of $10 \mathrm{mg} / \mathrm{kg}$ and for analgesia tramadol hydrochloride dose of $4 \mathrm{mg} / \mathrm{kg}$ subcutaneously. Medications were applied every 12 hours, for 5 postoperative days.

At the end of each evaluation time, animals were euthanized with an intravenous propofol dose of $10 \mathrm{mg} / \mathrm{kg}$ and $10 \%$ potassium chloride dose of $1 \mathrm{~mL} / \mathrm{kg}$ of body weight. Samples were continuously collected aseptically, avoiding contamination.

Immediately after collection, samples were conditioned for fixation in $10 \%$ buffered formaldehyde for a period of 48 hours, decalcified, washed, diaphanized and encased in paraffin to perform the cuts, hematoxylin and eosin (HE) stain.
The presence of neovascularization was evaluated in both peri- and intra-implant, as well as in the reaction to the presence of a foreign body (giant inflammatory cells close to the implants); both analyses were adapted using the criteria of Saghiri et al. (2015). The degree of inflammation was determined by the count of inflammatory cells (lymphocytes, macrophages, granulocytes and plasmocytes) present in the analysis area, following the criteria of Noetzel et al. (2006) and Panzarini et al. (2007), after adaptation. The formation of new bone tissue next to the implant was categorized following the criteria of Moretton et al. (2000), after adaptation. All analysis parameters are described in Table 1.

The data referring to histological evaluations (scores) were submitted to descriptive data analysis in an electronic spreadsheet (Microsoft Office Excel@) and later were compared by the Friedman test and Dunns post-test using $\mathrm{R}$ software (RTM Foundation for Statistical Computing, Austria). Significance (p-value) was fixed for all tests at $5 \%(\mathrm{p} \leq 0.05)$. 
Table 1. Description of the histological evaluation scores, after the adaptations by Noetzel et al. (2006), Panzarini et al. (2007), Moretton et al. (2000) and Saghiri et al. (2015). The presence of giant cells, neovascularization, number of inflammatory cells and woven bone were adopted for evaluation in scores

\begin{tabular}{c|c}
\hline Giant Cells & Description \\
\hline Score 0 & Absence of inflammatory giant cells. \\
\hline Score 1 & Presence of giant inflammatory cells near implant. \\
\hline
\end{tabular}

\begin{tabular}{c|c}
\hline Neovascularization & Description \\
\hline Score 0 & Absence of neovascularization \\
\hline Score 1 & Presence of neovascularization \\
\hline $\begin{array}{c}\text { Inflammatory } \\
\text { Cells }\end{array}$ & Description \\
\hline Score 0 & Absence of inflammatory cells in the analysis area. \\
\hline Score 1 & $\begin{array}{c}\text { Discrete inflammation - less than 25 inflammatory cells present in the analysis } \\
\text { area. }\end{array}$ \\
\hline Score 2 & Moderate inflammation - between 25-50 inflammatory cells present in the \\
analysis area.
\end{tabular}

\begin{tabular}{|c|c|}
\hline Woven Bone & Description \\
\hline Score 0 & Absence of formation of new woven bone. \\
\hline Score 1 & $\begin{array}{l}\text { Discreet - Presence of small bone trabeculae, covering less than } 25 \% \text { of the } \\
\text { implant area. }\end{array}$ \\
\hline Score 2 & Moderate - New bone tissue formed, covering at least $50 \%$ of the implant area \\
\hline Score 3 & $\begin{array}{c}\text { Extensive - Complete coverage of the implant area, with formation of a bone } \\
\text { bridge around the tested material. }\end{array}$ \\
\hline
\end{tabular}

\section{RESULTS}

In all samples of histological sections, neovascularization could be observed, and became more intense at 15 days and decreased over time (Figures 2A, 2B, and 3A).

There was presence of an immature fibrous tissue capsule, composed of several layers of active fibroblasts and immature collagen fibers around the entire bone implant (Figures $3 \mathrm{~B}$ and $4 \mathrm{~B}$ ). The capsule became thicker after 15 days (Figure 4B).

The presence of a chronic active inflammatory infiltrate composed of eosinophils, lymphocytes, plasmocytes, monocytes, macrophages and giant cells could be noted both in the capsule and in the connective tissue inside the implant (Figures $2 \mathrm{~B}$, $3 \mathrm{~B}$, and $4 \mathrm{~A}$ ). The inflammatory infiltrate was present in all times of analysis, that, over time, became predominantly lymphocytic.
Inside the bone trabeculae of the implant, there was also fibrous conjunctive tissue, hemorrhagic areas, and fibrin network, with evident neovascularization, that decreased after 30 days. The bone matrix of the implant was found in degenerative and fragmented processes throughout the analyses (Figures 2A, 3A, and 4A).

The inflammatory cells count was higher in subgroup A3 on the 7th day and in subgroup A1 on the 15th, 30th and 45th days than in the other groups $(p \leq 0.05)$ and was similar on the 60th day. There was a larger number of giant cells in subgroup A2 on the 45th day and subgroup A1 on the 30th day when compared to the other groups $(p \leq 0.05)$. There was no bone formation.

Neovascularization was similar in all groups during the period evaluated ( $\mathrm{p} \geq 0.05)$, however histologically, the presence of new vessels was seen in all times analyzed. 


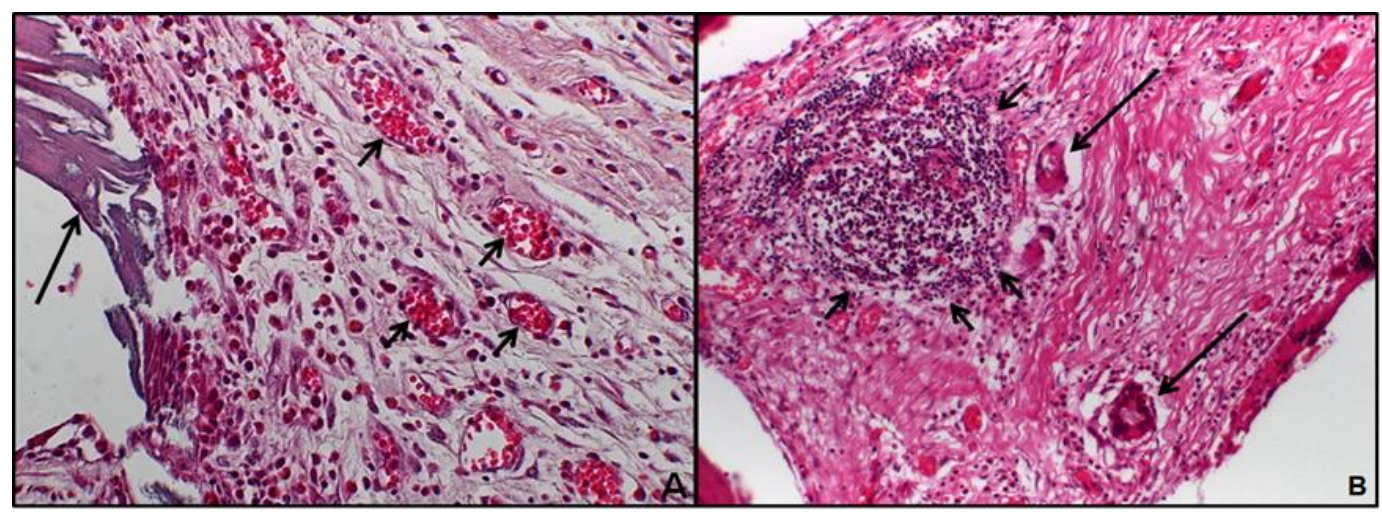

Figure 2. Photomicrograph of the implant of subgroup A1 (omental bag) collected from the rabbit bioreactor (Oryctolagus cuniculus) in 7 (A) and 30 days (B). A: Bone implant (long arrow) surrounded by connective tissue full of inflammatory cells and neovascularization (short arrows); HE stain, 10x objective. B: Presence of lymphocytic inflammatory reaction (short arrows) and giant cells of type foreign body around the bone matrix in process of degeneration; HE stain, 20x objective. Jaboticabal - SP, Brazil, 2021.

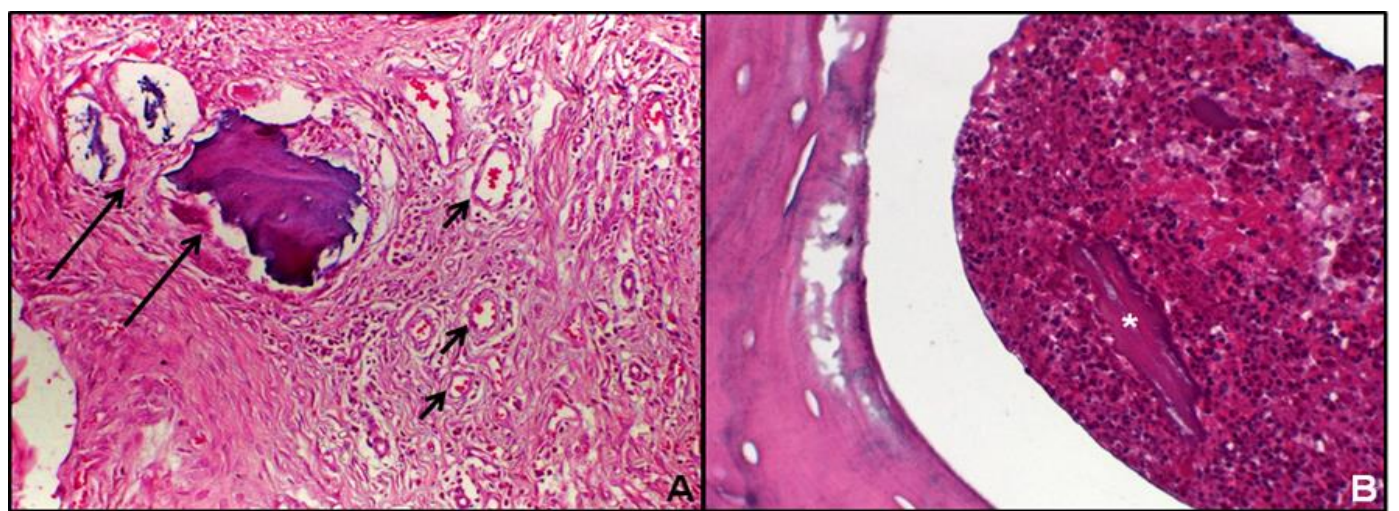

Figure 3. Photomicrograph of the implant of subgroup A2 (intermuscular) collected from the rabbit bioreactor (Oryctolagus cuniculus) in 15 (A) and 30 days (B). A: Presence of neovascularization (short arrows) and bone matrix of the implant in process of degeneration (long arrows); HE stain, 20x objective. $\mathrm{B}$ : Presence of neutrophilic inflammatory infiltrate close to that of bone implant (*) in 30 days; HE stain, 40x objective. Jaboticabal - SP, Brazil, 2021.

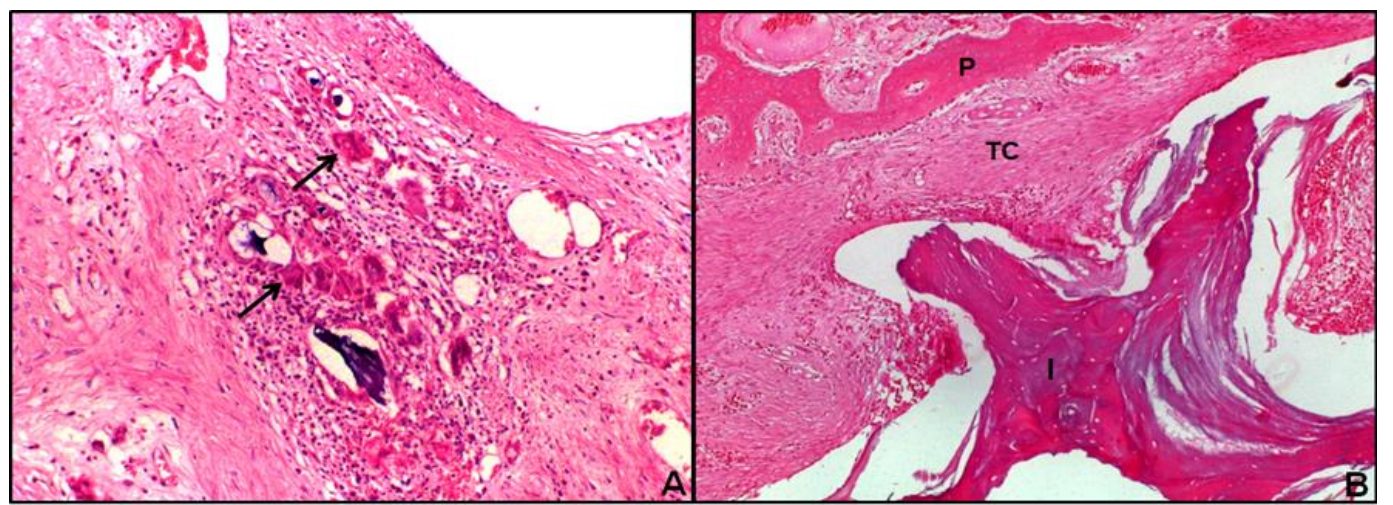

Figure 4. Photomicrograph of the implant of subgroupA3 (subperiosteal) collected from the rabbit bioreactor (Oryctolagus cuniculus) in 30 (A) and 45 days (B). A: Presence of foreign body type giant cells around the bone matrix (arrow); HE stain, 20x objective. B: Proliferation of connective tissue (CT) between the periosteum (P) and the implant (I); HE stain, 10x objective. Jaboticabal - SP, Brazil, 2021. 


\section{DISCUSSION}

The aim of this study was to evaluate angiogenesis in bovine xenografts implanted in rabbits' intracorporeal sites for future use as bone substitutes. When comparing the implant site, it was observed that the omentum is the site that best offers the ability to revascularize these grafts, but everywhere, the formation of new blood vessels was observed. With the formation of new vessels, we suggest that these implants that were previously housed in the bioreactors, may have a better osteoconductive and osteinductive capacity, since through the vessels the supply of oxygen, nutrients, pro-inflammatory factors, endothelial growth factors, among others it is guaranteed. The in vivo bioreactor model was recommended, since it has similar natural conditions of the biomaterial implanted for clinical use. Therefore, cell conditions, satisfactory blood supply, and inflammatory and growth factors natural to the organism itself can be maintained and may result in more reliable responses.

The bone fragments from bovine spongy bones were prepared by the team as a scaffold model, so their mechanical structure was kept in a geometric 3D cube shape. Thus, essential characteristics for the formation of bone tissue, such as the spongy structure, were maintained, as described by Liu and Ma (2004), Liu et al. (2007) and Roberts and Rosenbaum (2012). Any biomaterial used for bone replacement must be biocompatible, providing a porous anchoring surface for the cells that will develop and, over time, must be slowly reabsorbed, being replaced by new bone tissue formed (Athanasiou et al., 2009).

In the present study, the antigenic deproteinization method, as well as sterilization of the biomaterial, was implemented by autoclaving in a low cycle, comprising a 15 -minute exposure at $121^{\circ} \mathrm{C}$. When submitted to high temperatures, xenografts tend to lose their osteoinductive capacity, since part of the bone morphogenic proteins (BMPs) are denatured. BMPs initiate the differentiation of cartilage and bone progenitor cells, originating the formation of new bone tissue through endochondral ossification [21]. However, some commercial xenografts such as Bio-Oss ${ }^{\circledR}$ (Geistlich Biomaterials, Wolhusen, Switzerland) and Gen-Ox® (Baumer SA, São Paulo, Brazil) are prepared at higher temperatures, $300^{\circ} \mathrm{C}$ and $1000^{\circ} \mathrm{C}$, respectively, maintaining their osteoinductive properties (Accorsi-Mendonça $e t$ al., 2008).

Oliveira et al. (2003) compared the biocompatibility of bovine xenograft prepared by their team deproteinized at $100^{\circ} \mathrm{C}$ to a commercial one prepared at $1000^{\circ} \mathrm{C}$. The authors concluded that the commercial one showed better results, the tissue response to the implanted biomaterial was lower with complete deproteinization, not leading to much tissue losses and foreign body reaction. The xenograft prepared at $100^{\circ} \mathrm{C}$ was considered suitable for use as an osteoconductive material, and since it did not lose all its organic matter, part of the bone morphogenic proteins (BMPs) were not denatured. Thus, we can suggest that the same results occurred in the present study, since at similar temperatures, results were similar to the cited work, mainly in the inflammatory response observed in each analysis.

For tissue repair to occur within a graft, it is necessary for vascularization to appear in the new implanted tissue, because next to the new vessels, mineral deposition forms. Osteoconduction of biomaterial is linked to the number of new vessels formed in non-mineralized tissue (GalindoMoreno et al., 2018). In addition, the vascularization formed is responsible for forwarding growth factors and cytokines, which act in the graft as remodeling promoters (Athanasiou et al., 2009).

Histological analysis confirmed the presence of neovascularization at all times and sites of analysis, as it is widely reported in the literature (Simion et al., 2007; Araújo et al., 2009; Athanasiou et al., 2009; Mardas et al., 2010). Neovascularization was present in both peri and intra-implant tissues; and was more evident in subgroup A1 (omentum bag) due to the intense immunological, angiogenic, absorptive, adhesive, and adipocyte storage capacity of the organ (Huyghe et al., 2016). The angiogenic capacity of the omentum is given by the presence of the (VEGF), one of the main precursors of the development of vessels in the body (Zhang et al., 1997). In all groups, the number of newly formed vessels varied according to the times of analysis.

When implanting materials in soft tissues, a foreign body type inflammatory response is usually initiated, leading to the formation of a 
collagen tissue capsule. Collagen can be considered an excellent substrate for angiogenesis, mineral deposition and initiation of bone remodeling (Athanasiou et al., 2009). In the histological analysis, the presence of fibrous capsule in all implants was observed.

The presence of inflammatory cells and the amount of inflammation that affected the implanted biomaterial are some of the most important predictors of biocompatibility. Implant cellularity is the parameter that shows how graft remodeling is happening (Galindo-Moreno et al., 2018). The number of inflammatory cells, such as lymphocytes, macrophages, granulocytes, plasmocytes, monocytes, among others, were measured in histopathological analyses in the present study, demonstrating a greater amount in the A1 implant subgroup (omentum bag). In time analyses, mainly from the 15th day, inflammatory infiltrate had become predominantly lymphocytic. The fibrous capsule became denser, with considerable deposition of collagen and presence of fibroblasts, suggesting the beginning of a foreign body reaction.

Analysis showed that the subgroup A1 had the highest count of giant cells. The omentum is a very vascularized organ that can carry inflammatory cells more easily, probably for this reason there was a larger number of giant cells in this period. Foreign body type reactions are considered non-specific immune-mediated reactions and may start with the activation of the innate complement system and the participation of macrophage and monocyte lineages (Trindade et al., 2016). They form with the onset of chronic inflammation and occur when there is presence of giant cells at the interface of the biomaterial. Macrophages contain angiogenic and profibrogenic factors that regulate local fibrosis and angiogenesis. They generally adhere to the implant surface, modulating the formation of a fibrous capsule, which can assist or impair the implanted biomaterial function (Sheikh et al., 2015). They respond to most types of biomaterials and adhere to the walls, but it has not yet been concluded how this mechanism occurs (Anderson et al., 2008).

It is possible to affirm that macrophages and giant cells are among the inflammatory cells from the histological analysis of the present clinical trial samples. Knowing the functions and possibilities this phagocytic lineage is capable of, we suggest it may directly influence the results, since the presence of giant cells was observed and that may be linked with macrophage cell fusion. This explains the fact that implant degeneration occurs over time.

Due to the formation of tissue capsules, it is considered that foreign body reaction was activated by antigenic particles present in the bone matrix that were not completely deproteinized. The deproteinization and sterilization method used was enough so that bacterial infections were not present at the implant sites, once the reactions were all aseptic, but the antigenicity was partially maintained. The immune system is often seen as a negative factor for tissue repair, but studies show that its modulation can stimulate regeneration (Simion et al., 2007; Araújo et al., 2009; Mardas et al., 2010). This may have been the biggest limitation of the study, as there is a lack of described methods for ideal xenograft preparations that lead to balanced inflammatory and immune reactions.

\section{CONCLUSION}

It is concluded that the bioreactor technique is easily performed, as long as the biomaterial implantation sites do not pose any risk to the patient and at the same time are easily accessible. In this work, the omentum was the site that offered favorable results for its use as an implant site within the bioreactor and the best day for this implant to be used in a bone failure would be close to the 15th day, since at this time there is a favorable presence of vascularization, inflammatory cells that can favor the bone repair process and there is still no presence of foreign body reaction.

In addition, this technique can be applied to the use of various biomaterials, as well as other types of grafts, such as allografts preserved in glycerin, since under the conditions in which this project was carried out, it can also be concluded that neovascularization is possible in bovine xenografts implanted as in vivo bioreactors. With neovascularized xenografts, it is suggested that they have osteoconductive and osteoinductive capacity and may be viable and cheap alternatives for the reconstruction of bone defects. 


\section{ACKNOWLEDGEMENTS}

FAPESP and CAPES / São Paulo State Research Support Foundation process $n^{\circ}$ 2017/04142-5. To $\mathrm{CNPq}$ - National Council for Scientific and Technological Development.

\section{REFERENCES}

ACCORSI-MENDONÇA, T.; CONZ, M.B.; BARROS, T.C. et al. Physicochemical characterization of two deproteinized bovine xenografts. Braz. Oral Res., v.22, p.5-10, 2008.

ANDERSON, J.M.; RODRIGUEZ, A.; CHANG, D. T. Foreign body reaction to biomaterials. Semin. Immunol., v.20, p. 86-10, 2008.

ARAÚJO, M.; LINDER, E.; LINDHE, J. Effect of a xenograft on early bone formation in extraction sockets: an experimental study in dog. Clin. Oral Implants, v.20, p.1-6, 2009.

ATHANASIOU, V.T.; PAPACHRISTOU, D.J.; PANAGOPOULOS, A. et al. Histological comparison of autograft, allograft-DBM, xenograft, and synthetic grafts in a trabecular bone defect: an experimental study in rabbits. Med. Sci. Monit., v.16, p.BR24-BR31, 2009.

CASTRO-SILVA, I.L.; ZAMBUZZI, W.F.; GRANJEIRO, J.M. Panorama atual do uso de xenoenxertos na prática odontológica. $J$. Biomater. Esthet., v.4, p.70-75, 2009.

CROCI, T.A.; BITAR, G.; PEREIRA, S.L.B. et al. Efeito do concentrado de plasma em falhas ósseas provocadas em fêmures de camundongos como estimulação de formação óssea: estudo experimental. Acta Ortop. Bras., v.11, p.230-239, 2003.

GALINDO- MORENO, P.; BUITRAGO, J.G.; PADIAL- MOLINA, M. et al. Histopathological comparison of healing after maxillary sinus augmentation using xenograft mixed with autogenous bone versus allograft mixed with autogenous bone. Clin. Oral Implants, v.29, p.192-201, 2018.

GUTIERRES, M.; LOPES, M.A.; HUSSAIN, N.S. et al. Substitutos Ósseos: conceitos gerais e estado actual. Arq. Med., v.19, p.153-162, 2005.
HUANG, J.J.; YANG, S.R.; CHU, I.M. et al. A comparative study of the chondrogenic potential between synthetic and natural scaffolds in an in vivo bioreactor. Sci. Technol. Adv. Mater., v.14, p.054403, 2013.

HUYGHE, S.; ROOSTER, H.; DOOM, M. et al. The microscopic structure of the omentum in healthy dogs: the mystery unravelled. Anat. Histol. Embryol., v.45, p.209-218, 2016.

JOHNSON, K.A. The pelvis and hip joint. In: Piermattei's atlas of surgical approaches to the bones and joints of the dog and cat. St. Louis, Missouri: Elsevier, 2014. p.315-369.

KEATING, J.F.; MCQUEEN, M.M. Substitutes for autologous bone graft in orthopaedic trauma. J. Bone Joint. Surg. A, v.83, p.3-8, 2001.

LIMA TAGA, M.L.; GRANJEIRO, J.M.; CESTARI, T.M. et al. Healing of critical-size cranial defects in guinea pigs using a bovine bonederived resorbable membrane. Int. J. Oral Maxillofac. Implants, v.23, p.427-436, 2008.

LIU, C.; XIA, Z.; CZERNUSZKA, J.T. Design and development of three-dimensional scaffolds for tissue engineering. Chem. Eng. Res. Des., v.85, p.1051-1064, 2007.

LIU, X.; MA, X. Polymeric scaffolds for bone tissue engineering. Annu. Rev. Biomed. Eng., v. 32, n. 3, p. 477-486, 2004.

MARDAS, N.; CHADHA, V.; DONOS, N. Alveolar ridge preservation with guided bone regeneration and a synthetic bone substitute or a bovine- derived xenograft: a randomized, controlled clinical trial. Clin. Oral Implants Res., v.21, p.688-698, 2010.

MORETTON, T.R.; BROWN JR, C.E.; LEGAN, J.J. et al. Tissue reactions after subcutaneous and intraosseous implantation of mineral trioxide aggregate and ethoxybenzoic acid cement. $J$. Biomed. Mater. Res., v.52, p.528-533, 2000.

NOETZEL, J.; ÖZER, K.; REISSHAUER, B.H. et al. Tissue responses to an experimental calcium phosphate cement and mineral trioxide aggregate as materials for furcation perforation repair: a histological study in dogs. Clin. Oral Invest., v.10, p.77-83, 2006 
OLIVEIRA, R.C.D.; MENEZES, R.; CESTARI, T.M. et al. Tissue response to a membrane of demineralized bovine cortical bone implanted in the subcutaneous tissue of rats. Braz. Dent. J., v.15, p.3-8, 2004.

OLIVEIRA, R.C.D.; SICCA, C.M.; SILVA, T.L. et al. Avaliação histológica e bioquímica da resposta celular ao enxerto de osso cortical bovino previamente submetido a altas temperaturas. Efeito da temperatura no preparo de enxerto xenógeno. Rev. Bras. Ortop., p.551-560, 2003.

PANZARINI, S.R.; HOLLAND, R.; SOUZA, V. et al. Mineral trioxide aggregate as a root canal filling material in reimplanted teeth. Microscopic analysis in monkeys. Dent. Traumatol., v.23, p.265-272, 2007.

ROBERTS, T.T.; ROSENBAUM, A.J. Bone grafts, bone substitutes and orthobiologics: the bridge between basic science and clinical advancements in fracture healing. Organogenesis, v.8, p.114-124, 2012.

SAGHIRI, M.A.; ORANGI, J.; TANIDEH, N. et al. Repair of bone defect by nano-modified white mineral trioxide aggregates in rabbit: a histopathological study. Med. Oral Patol. Oral Cir. Bucal, v.20, p.e525, 2015.

SHEIKH, Z.; BROOKS, P.; BARZILAY, O. et al. Macrophages, foreign body giant cells and their response to implantable biomaterials. Materials, v.8, p.5671-5701, 2015.
SIMION, M.; FONTANA, F.; RASPERINI, G. et al. Vertical ridge augmentation by expandedpolytetrafluoroethylene membrane and a combination of intraoral autogenous bone graft and deproteinized anorganic bovine bone (Bio Oss). Clin. Oral Implants Res., v.18, p.620-629, 2007.

STEVENS, M.M.; MARIINI, R.P.; SCHAEFER, D. et al. In vivo engineering of organs: the bone bioreactor. Proc. Natl. Acad. Sci., v.102, p.1145011455, 2005.

TRINDADE, R.; ALBREKTSSON, T.; TENGVALL, P. et al. Foreign body reaction to biomaterials: on mechanisms for buildup and breakdown of osseointegration. Clin. Implant Dent. Relat. Res., v.18, p.192-203, 2016.

URIEL, S.; HUANG, J.J.; MOYA, M.L. et al. The role of adipose protein derived hydrogels in adipogenesis. Biomaterials, v.29, p.3712-3719, 2008.

ZHANG, Q.X.; MAGOVERN, C.J.; MACK, C.A. et al. Vascular endothelial growth factor is the major angiogenic factor in omentum: mechanism of the omentum-mediated angiogenesis. J. Surg. Educ., v.67, p.147-154, 1997. 